\title{
Influence of Limestone Powder as Partial Replacement of Cement on Concrete and the Effect of High Temperature on It
}

\author{
Dr. Abdul Hakeem Hamed Ahmed \\ Professor \\ Rana Burhan Abdurrahman \\ Assistant lecturer \\ Zena Adel Mohammed \\ Assistant lecturer
}

Civ. Engrg. Dept./ Mosul Univ.

\begin{abstract}
In the recent years, the uses of the binding materials of different types in addition to cement become very wide in the product of concrete as blending of portland cement with limestone, so it is necessary to investigate the influence of the binder material on the concrete properties. In order to asses the performance of this type of concrete, it is important to understand the changes in the concrete properties especially in case of exposure to elevated temperature.

This paper summarize and discuss the effect of the limestone powder $\left(\mathrm{CaCO}_{3}\right)$ as a compensating material with cement on the compressive and tensile strength and discuss the effect of elevated temperature on this type of concrete.

Limestone powder (LP) was used as a compensating material with different ratio of cement include $(0,10,15,20,25) \%$. Compressive and tensile strength were investigated before and after the exposure to high temperature including $(200,400,600){ }^{\circ} \mathrm{C}$.

The study show that limestone compensate changes in both compressive, and tensile strengths. Negative effects on the properties observed as the amount of limestone exceeds $15 \%$ of the cement weight. After the exposure to high temperature the results show a drop in compressive and tensile strengths in a different form.
\end{abstract}

Key words: Limestone powder; elevated temperature

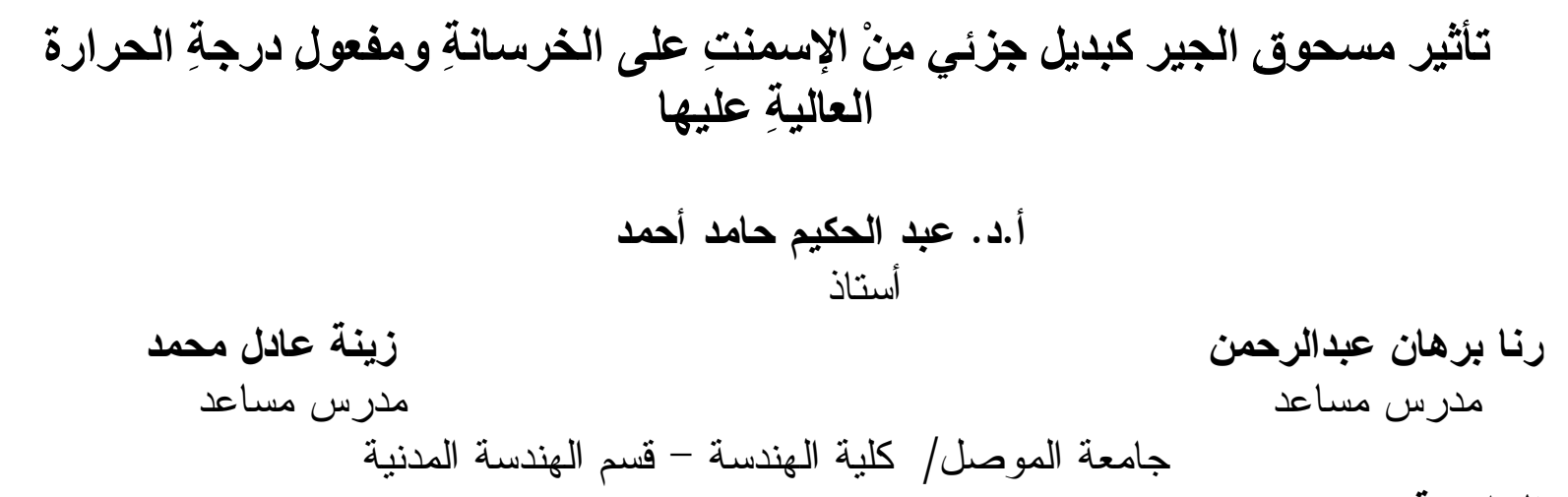

الخلاصة

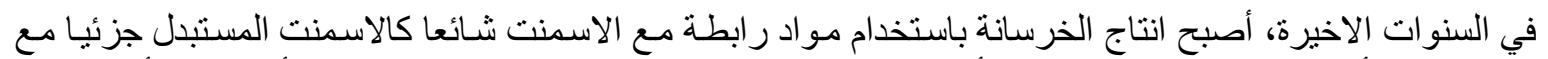

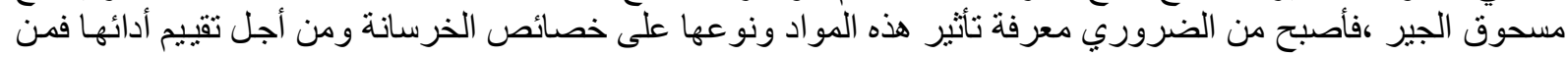

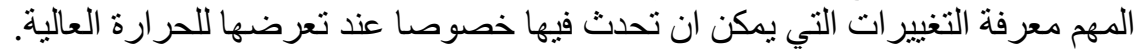

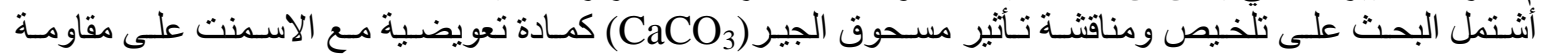

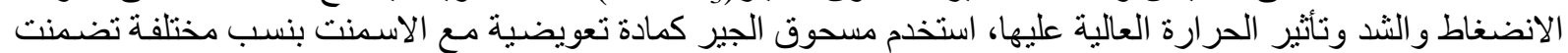

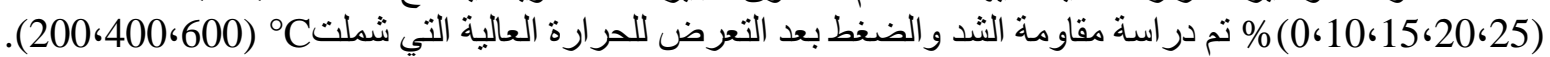

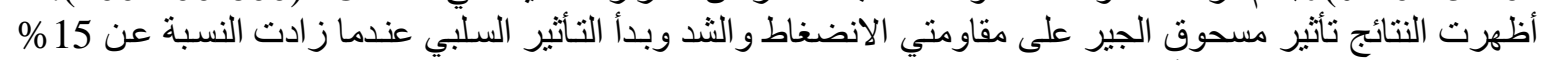

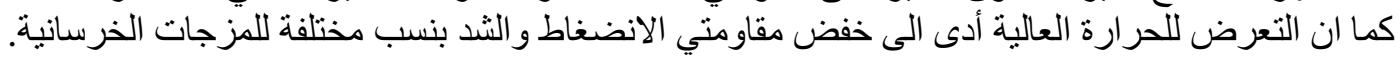




\section{Introduction}

Most cement plants consume much energy and produce a large amount of undesirable products, which affect the environment. In order to reduce energy consumption and $\mathrm{CO} 2$ emission and increase production, cement manufacturers are blending mineral additions such as slag, natural pozzolan, sand and limestone [Ghrici et al, 2007], limestone has been used in concrete production for the last 25 years, not only for the main purposes of lowering the costs and environmental load of cement production, but also to increase the concrete durability, more recently limestone is also used as a filler material to improve the workability and stability of fresh concrete and for a high flowable concrete, such as self-compacting concrete. [Esping, 2008]. Civil structures may expose to an elevated temperature or used for high temperature conditions, such as nuclear reactors, industrial furnaces and building exposed to accidental fire conditions. Therefore, fire resistance of structural elements has become an integral part of the design, the mechanical properties of all building materials at ambient and high temperature conditions are of interest and has, therefore, received special attention in the literatures. The fire resistance capacity of concrete is very complicated because not only the concrete is a composite material with components having different thermal characteristics, but also has properties that depend on moisture content and porosity [Shah et al, 1994], to determine the resistance of concrete samples exposed to high temperature, many test methods are used, three test methods are commonly referred in most experimental programs on the fire performance of concretes. In unstressed residual strength test method, the specimen is heated without preload at a prescribed rate to the target temperature, which is maintained until a thermal steady state is reached within the specimen. The specimen is then allowed to cool, following a prescribed rate, to room temperature. Load or strain is applied at room temperature until the specimen fails [Phan, 1996]. Unstressed residual strength test method was used in this study. In this paper, the characteristics of four different conventional concretes of different LP partial replacement of cement in fresh and hard concrete subjected to high temperatures up to $600^{\circ} \mathrm{C}$ were experimentally investigated, these characteristics are very important for the safe design of concrete and in the repair of concrete structure.

\section{Experimental Details}

\section{1: Materials}

The cement materials used in this study were ordinary Portland cement (PC) equivalent to Iraqi standard (IQS 5 - 1984); the properties of the cement are shown in Table (1).

Table (1) Properties of cement

Chemical composition*

\begin{tabular}{|l|c|c|c|c|c|c|}
\hline Oxide Composition & $\mathrm{SiO}_{2}$ & $\mathrm{Fe}_{2} \mathrm{O}_{3}$ & $\mathrm{Al}_{2} \mathrm{O3}$ & $\mathrm{CaO}$ & $\mathrm{MgO}$ & $\mathrm{SO}_{3}$ \\
\hline Content (\%) & 20.6 & 2.68 & 5.32 & 62.7 & 2.8 & 2.27 \\
\hline Mineralogical components & \multicolumn{2}{|c|}{$\mathrm{C} 3 \mathrm{~S}$} & $\mathrm{C} 2 \mathrm{~S}$ & $\mathrm{C3A}$ & \multicolumn{2}{c|}{$\mathrm{C4AF}$} \\
\hline Content (\%) & \multicolumn{2}{|c|}{41.53} & 27.97 & 9.57 & 8.15 \\
\hline
\end{tabular}

Mechanical properties

\begin{tabular}{|c|c|c|}
\hline Age (day) & Compressive strength (MPa) & Tensile strength (MPa) \\
\hline $\mathbf{3}$ & 15.5 & 1.5 \\
\hline $\mathbf{7}$ & 24.1 & 2.36 \\
\hline Physical properties & Final \\
\hline Setting & Initial & 200 \\
\hline time (min) & 120 & \\
\hline
\end{tabular}

* Data are given by the manufacturer 
The coarse aggregate used was a river rounded gravel with maximum aggregate size (12.5) mm equivalent to (B.S 812:1992) as shown in Fig. (1). A river sand with fineness modulus of 2.46 equivalent to (B.S 812:1992) was also used as a fine aggregate as shown in Fig. (2), city tap water was used in the mixes. LP was used in the mixes has a fineness of $0.15 \mu \mathrm{m}$.

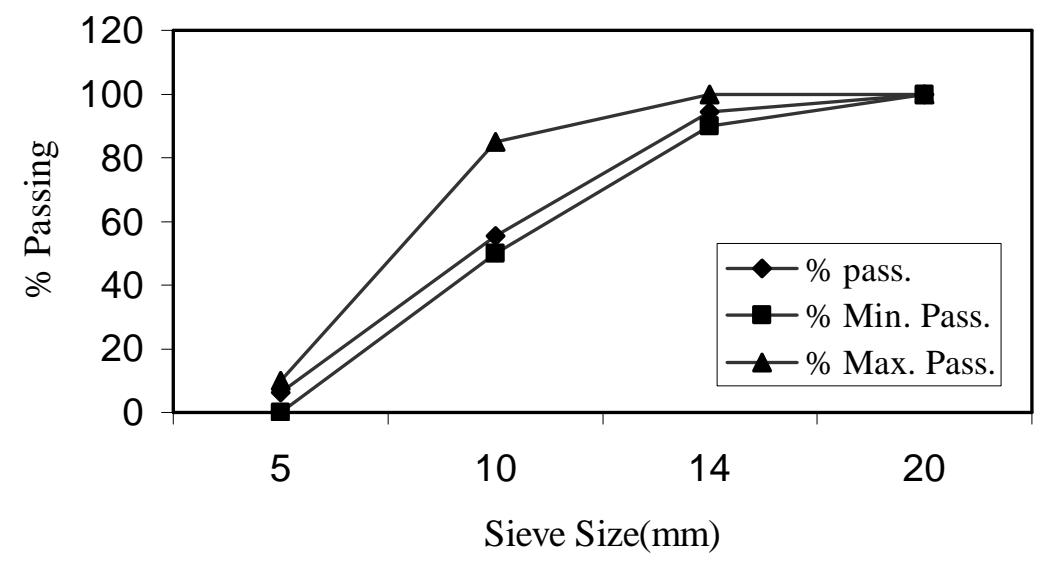

Fig. (1): Graduation of coarse aggregate

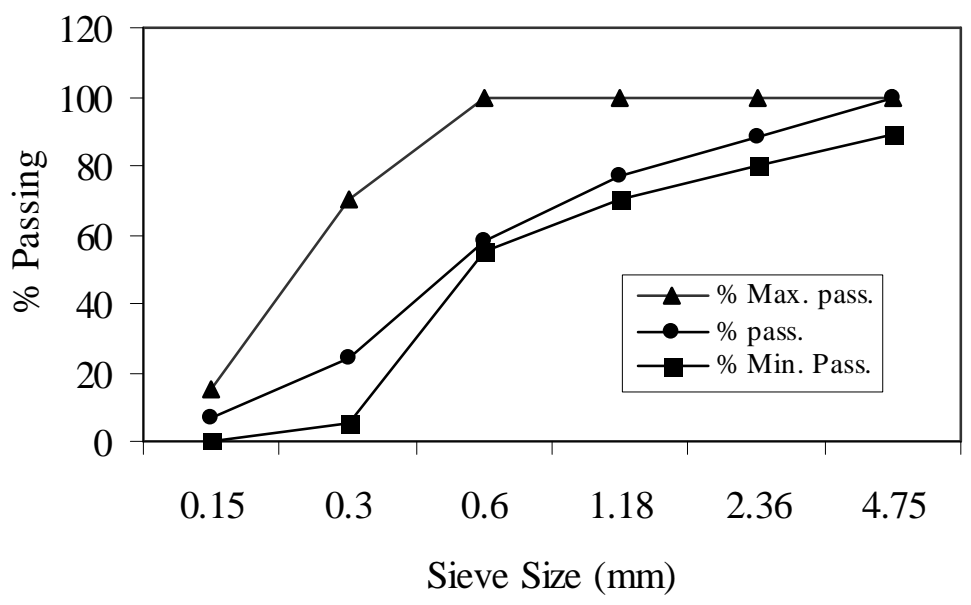

Fig. (2): Graduation of fine aggregate

\section{2: Mix Proportioning}

Five concrete mixes were prepared with LP as a cement compensating levels of $(0,10,15$, $20,25) \%$ by weight chosen after many trail mixes [Lothenbach et al, 2008]. All the concrete mixes were prepared at a water to binder (cement + LP) materials ratio of 0.46 , the details of mix proportions (1 Binder: 1.75 Fine agg.: 2.9 Coarse agg $/ 0.46 \mathrm{w} / \mathrm{b}$ ) are shown in Table (2). 
Table (2): Mix proportions $\left(\mathrm{kg} / \mathrm{m}^{3}\right)$

\begin{tabular}{|c|c|c|c|c|c|}
\hline mixture & cement & sand & gravel & water & LP \\
\hline LP-0 & 390 & 682.5 & 1131 & 179.4 & 0 \\
\hline LP-10 & 351 & 682.5 & 1131 & 179.4 & 39 \\
\hline LP-15 & 331.5 & 682.5 & 1131 & 179.4 & 58.5 \\
\hline LP-20 & 312 & 682.5 & 1131 & 179.4 & 78 \\
\hline LP-25 & 292.5 & 682.5 & 1131 & 179.4 & 97.5 \\
\hline
\end{tabular}

\section{3: Specimen Preparation and Test}

Concrete mixtures were made in a laboratory pan mixer. The aggregate, cement and LP were placed first and mixed at dry condition for about $2 \mathrm{~min}$. After that, water was added, followed by another $2 \mathrm{~min}$ of mixing, slump was found according to (ASTM C143) to determine the concrete mixes workability. The batch was cast in twelve $100 \times 100 \times 100 \mathrm{~mm}^{3}$ cubic steel moulds and twelve $100 \times 200 \mathrm{~mm}^{2}$ cylinder steel moulds, then compacted using a vibration table. The specimen were cured in water for 14 days then cured at air dry condition at room temperature $(20 \pm 1){ }^{\circ} \mathrm{C}$ for another 14 days. An electric furnace of maximum $600{ }^{\circ} \mathrm{C}$ was used .The specimens at age of 28 days were exposed to the desired temperatures for one hour without any load. Residual mechanical properties were determined including compressive and tensile strength according to (BS 1881: Part 116) and (ASTM C496) respectively. Initial setting time was also measured according to (ASTM C191).

\section{Result and Discussion}

\section{1: Initial Setting Time and Slump}

The effect of partial replacement of cement with LP on the initial setting time and slump are shown in Figs. $(3,4)$ respectively (average of three samples), the initial setting time decreased to about 75 minute for the LP compensate with cement at amounts of $(15,20) \%$, then increased to 90 minute at the maximum amount of compensating (25\%). Apart from calcareous filler having a quite limited chemical interaction with hydration product, it has been shown that a chemical reaction of calcite $\mathrm{CaCO}_{3}$ with $\mathrm{C} 3 \mathrm{~A}$ reactivity appears, yet the extent of calcareous filler chemical activity is generally admitted to be very limited [Hawkins et al, 2003]. As filler generally replaces cement there is a dilution effect, the cement paste amount decrease [Lawrence et al, 2005], these affected on time of initial setting.

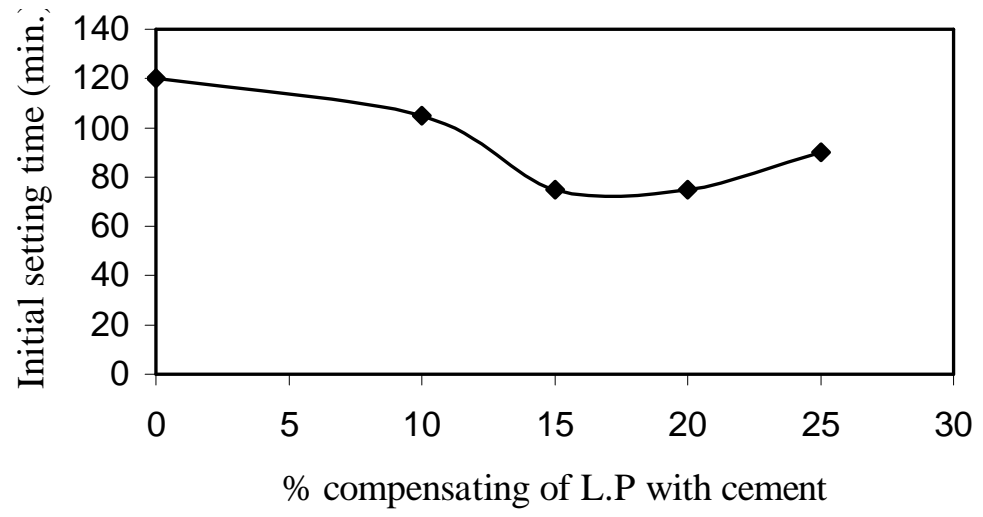

Fig (3): Effect of LP partial replacement with cement on in. setting time 
Slump decrease to $72 \mathrm{~mm}$ with $10 \%$ compensating of cement with LP, and recovered to $75 \mathrm{~mm}$ at amount $15 \%$ of compensating. The increasing of compensating of cement with LP, increase in slump ranged from $7 \%$ at $20 \%$ of compensating and expanded to $11 \%$ at amount $25 \%$ of compensating. Water is getting adsorbed at the surface of filler particles. As fillers specific surface is higher than that of sand, slump decrease due to adsorption phenomenon. As filler particles fill up voids, filler occupies the place of sand with smooth surface particles which reduced the inter particle fraction that increase slump [Benachour et al, 2008].

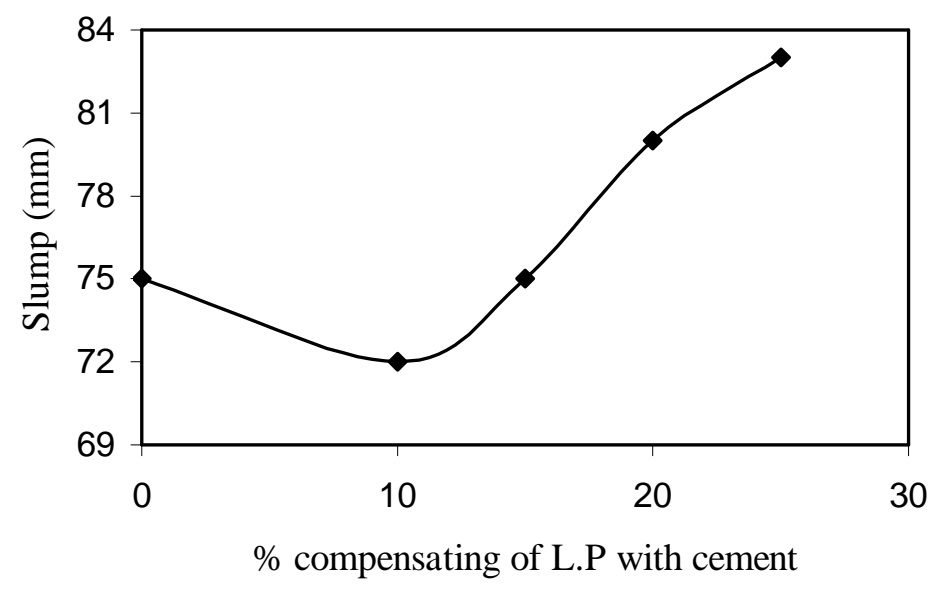

Fig (4): Effect of LP partial replacement with cement on slump

\section{2: Concrete Density}

Concrete is a porous material having discrete and interconnected pores of different sizes and shapes, the use of cement replacement materials result in achieving pore size refinement.

Fig(5) shows the variation of concrete density with the percent of LP as a partial replacement with cement, the density increase up to an optimal value at amount $15 \%$ componsating and then decrease for higher proportion. This is interpreted as filler powder first filling voids around sand grains, up to the optimum. For higher filler amounts, those voids being completely filled, filler powder then occupies the place of sand grains, hence diminishing sand proportion, and consequently the mix density [Bédérina et al, 2005]

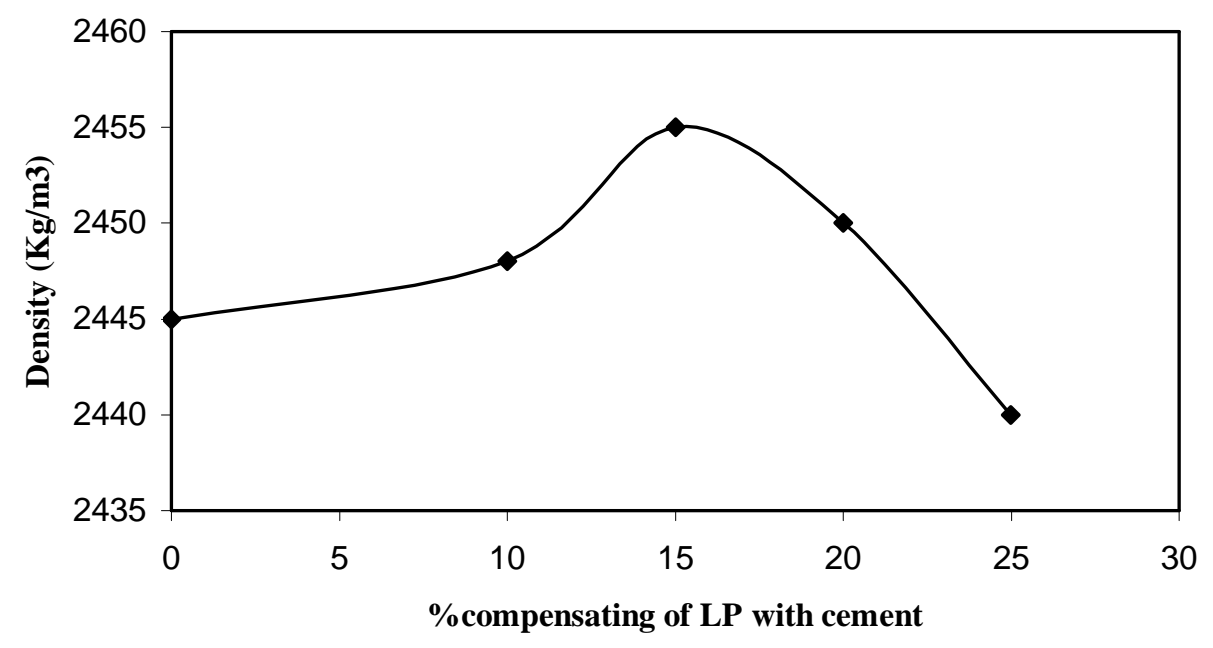

Fig(5):Variation of density as a function of LP mass percentage. 
When hardened concrete exposed to high temperature, loss of density due to loss of weight appears to take place due to evaporation of water from large capillaries and voids. Between $100^{\circ} \mathrm{C}$ and $600{ }^{\circ} \mathrm{C}$ loss of non evaporable water from gel pores and small capillary pores will take place [Ravindrarajah et al, 2002].

Fig.(6) shows the density losses at elevated temperature of the investigation mixtures of the cube specimens, concrete mixture compensating with $10 \%$ limestone powder act like normal concrete in density lost but more loss in density at $600^{\circ} \mathrm{C}$, other concrete mixtures compensating with limestone powder exhibit less density loss than the normal concrete this is so clear at $400^{\circ} \mathrm{C}$ and $600^{\circ} \mathrm{C}$, this attributed to the lower porosity of concrete mixtures compensating with limestone powder than normal concrete [Lothenbach et al,2008].

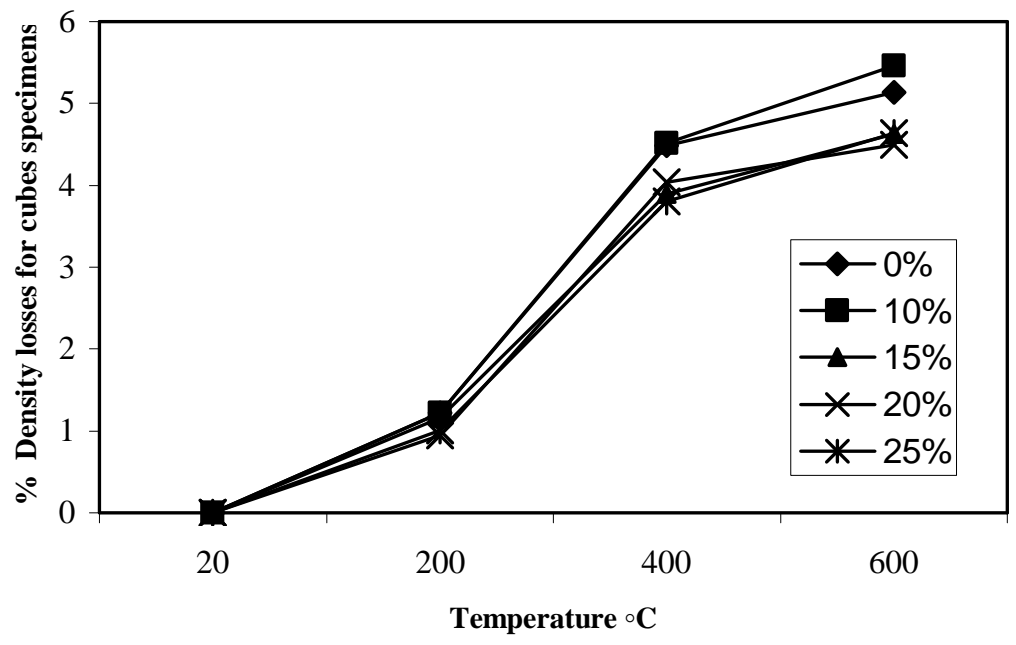

Fig (6) Density losses of concrete cube specimens

\section{2: Compressive Strength}

Fig.(7) shows the variation of compressive strength with \% variation of LP for different temperature. For the unheated specimens, it can be seen that a $15 \%$ compensating increase the compressive strength by $8.96 \%$ comparing with the $20 \%$ compensating which resulted in less increase of $5.83 \%$ in the compressive strength, several combined effects may be called upon to explain strength maintenance. In presence of filler, the solid skeleton may be strengthened thanks to a more homogeneous distribution of smaller $\mathrm{C}-\mathrm{S}-\mathrm{H}$ crystals, finer pore structure, accelerated cement hydration [Moosberg-Bustnes et al, 2004], Moreover, the bond between cement paste and sand particles may be strengthened thanks to the reduction of the wall effect provided by the fine particles filling [Lawrence et al, 2005].

beyond an optimal value of LP addition (determined at $15 \%$ compensating in this study), the amount of fines increases so much that the cement paste is not able to coat all fine and coarse particles ,so drop in the reactive clinker component results in significant physical modifications of the material [Lothenbach et al,2008]. This phenomenon weakens the cement-to aggregate bond and hence leads to a loss in compressive strength for higher filler amounts than the optimal value [Celik et al, 1996], so $25 \%$ compensating resulted in decrease of $1.85 \%$ in the compressive strength. 


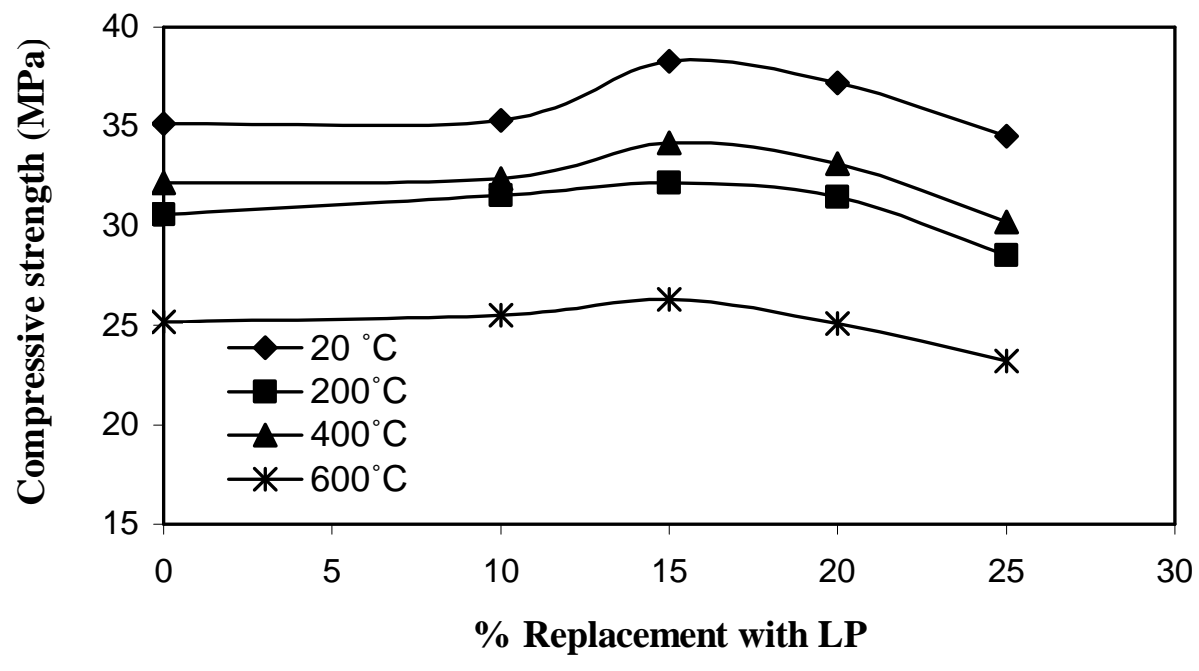

Fig (7): variation of compressive strength with replacement of LP

Fig.(8) shows the decrease in compressive strength with elevated temperature, it can be seen that all the concrete mixtures exhibited strength losses at $200^{\circ} \mathrm{C}$ then gained strength at $400{ }^{\circ} \mathrm{C}$ to a value nearly equal or more than $200{ }^{\circ} \mathrm{C}$ this may be attributed to some hydration of the cement paste at this temperature that did not occur at lower temperature. Above $400{ }^{\circ} \mathrm{C}$ all types of concrete loss their strength at faster rate, at this temperature the dehydration of the cement paste results in its gradual disintegration. Since the paste tends to shrink and aggregate expands at high temperature (different thermal expansion at temperature above $100{ }^{\circ} \mathrm{C}$ ), the bond between the aggregate and the paste is weakened, thus reducing the strength of concrete.

The replacement of cement by limestone powder increase the decrease in compressive strength after exposure to elevated temperature this resulted by the dense micro structures which led to the build up of high internal pressure during heating [Poon et al, 2001].

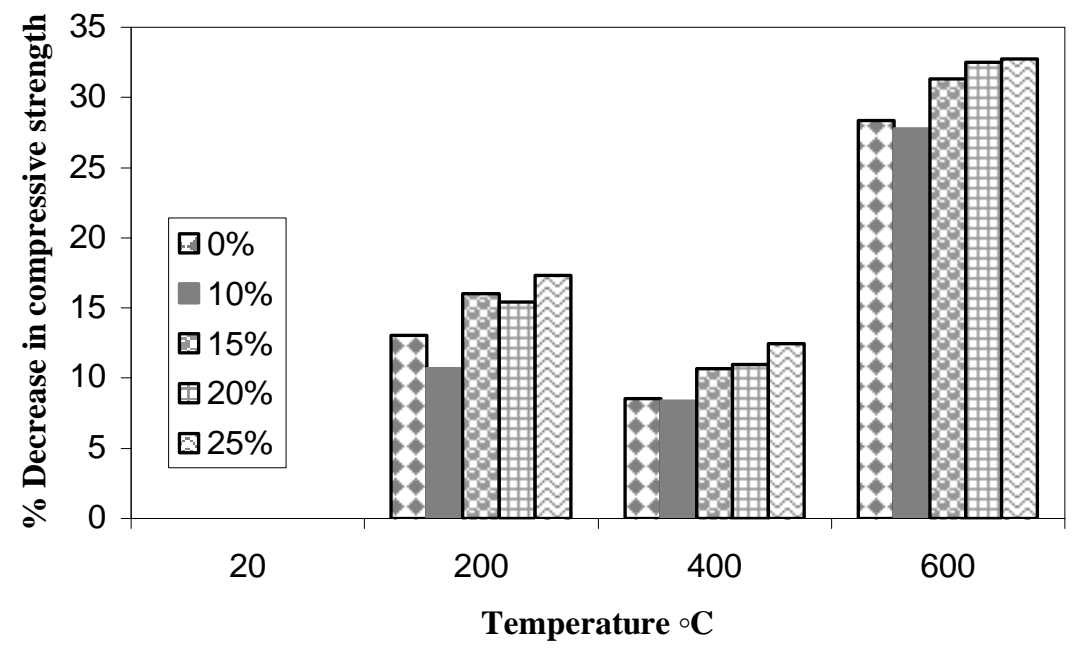

Fig (8) Decrease in compressive strength with temperature

\section{3: Splitting Tensile Strength}

Fig.(9) show the average tensile strength, it can be seen that the replacement of cement by limestone powder resulted in an increase of splitting tensile strength up to $15 \%$ then decrease. 
For the unheated specimens, the increase in tensile strength expanded to be $13.62 \%$ at $15 \%$ compensating then decrease with the increase of LP replacement.

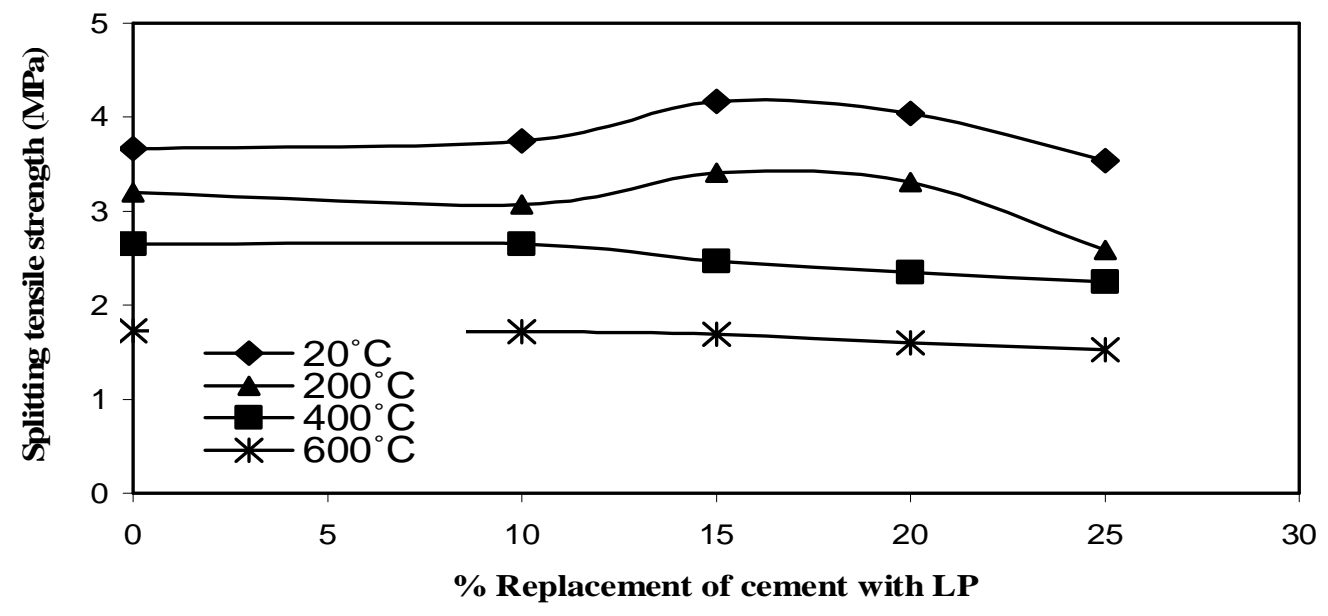

Fig (9): variation of splitting tensile strength with replacement of LP

Tensile strength showed significant losses with the increase in exposure temperature, this is so clear in Fig.(10), the residual tensile strength of concrete mixtures at $200{ }^{\circ} \mathrm{C}$ started from $87.19 \%$ for normal concrete and the residual decrease with the increase of compensating to be $73.2 \%$ at $25 \%$, at $400{ }^{\circ} \mathrm{C}$ the residual tensile strength of normal concrete $72.2 \%$ then decrease when cement compensating by limestone powder at $20 \%$ to be $58.2 \%$, no significant change in tensile strength at $600{ }^{\circ} \mathrm{C}$, the residual tensile strength of normal concrete $47.1 \%$ while $20 \%$ compensating exhibit $40 \%$ residual strength.

The loss in tensile strength is considerably sharp, which is clearly different from the loss of compressive strength, this is because the tensile strength is more sensitive to macro- or non micro-scale cracks, which are caused by high temperature to concrete[Chan et al, 1999].

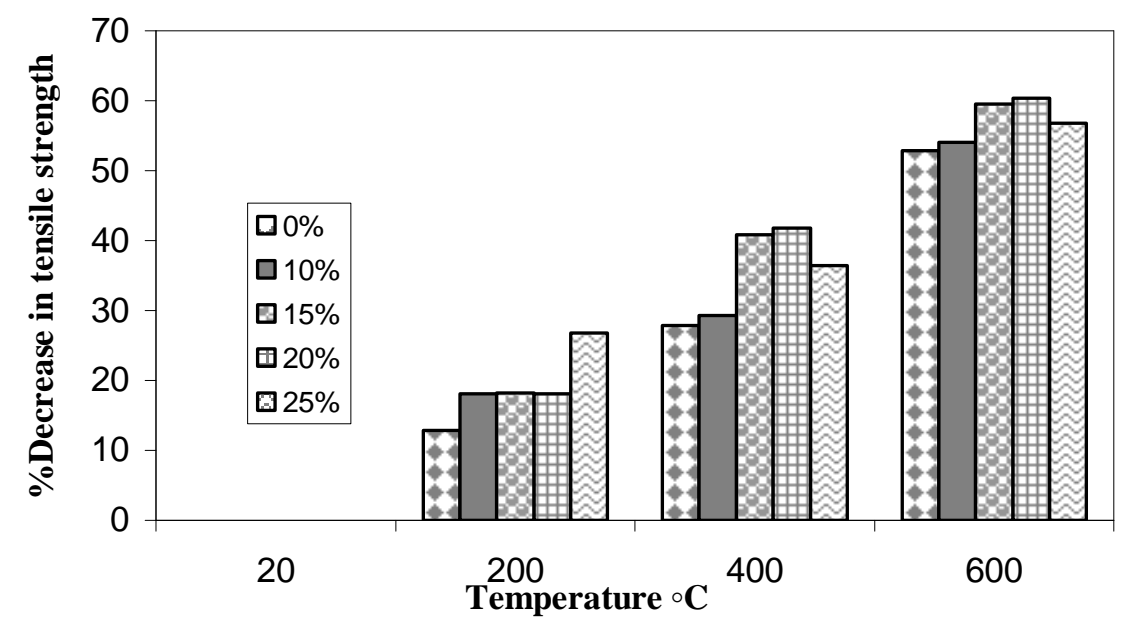

Fig (10): Decrease in tensile strength with temperature

\section{Conclusions}

This research study exhibit the feasibility of the use of LP as cement partial replacement in concrete mixes and studies the effect of elevated temperature on the compressive, and tensile strengths. The following conclusions could be extracted from this study:

1- LP offers a number of advantage for its use as cement compensating by enhance flow properties and increase compressive strength. 
2-The slump of concrete relatively increase with higher values of the percentage of compensating of cement with LP.

3-Based on the results, it was observed that the compressive strength of concrete increase with the increase in LP compensating, concrete made with 15\% LP compensating showed higher compressive strength.

4-In general, the compressive strength of LP concrete, like that of normal concrete, decrease with increasing temperature. At $400^{\circ} \mathrm{C}$ a higher value in the compressive strength is observed to that at $200{ }^{\circ} \mathrm{C}$ is observed.

\section{References}

Ghrici M., Kenai, S., Said-Mansour, M. "Mechanical properties and durability of mortar and concrete containing natural pozzolana and limestone blended cements" Cement \& Concrete Composites, vol. 29, 2007, pp: 542-549

Esping, O., "Effect of limestone filler BET(H2O)-area on the fresh and hardened properties of self-compacting concrete", Cement and Concrete Research, vol. 38, 2008, pp: 938944

Shah, S.P. , Ahmad, S.H. , "High Performance Concrete: Properties and Applications", McGraw-Hill, 1994.

Phan LT. "Fire performance of high-strength concrete: a report of the state-of-the- art. Gaithersburg”, Maryland: NISTIR 5934, Building and Fire Research laboratory, National Institute of Standards and Technology; 1996.

Iraqi Standard Specification No.5 (1984)," Properties of Ordinary Portland Cement", Iraq, 1984.

BS 882-1992,"Aggregate from Natural Source for Concrete”, British Standard Institution, 1992

Lothenbach, B., Saout, G., Gallucci, E., Scrivener, K.," Influence of limestone on the hydration of Portland cements", Cement and Concrete Research, vol. 38, 2008, pp: 848-860.

ASTM C143-04, "Slump of Hydraulic-Cement Concrete” ,American Society for Testing and Materials, 2004.

BS 1881:part116:1983”Testing of Hardened Concrete”, British Standard Institution, 1983.

ASTM C496-04, "Splitting Tensile Strength of Cylindrical Concrete Specimens” ,American Society for Testing and Materials, 2004.

ASTM C191, "Method of Test for Time of Setting of Hydraulic-Cement by Vicat needle" ,American Society for Testing and Materials,2004.

Hawkins, P., Tennis, P., Detwiler, R., "The use of limestone in Portland cement: a state ofthe-art review”, Portland Cement Association, 2003 Report n. EB227.

Lawrence, P., Cyr, M., Ringot, E.," Mineral admixtures in mortars: effect of type, amount and fineness of fine constituents on compressive strength", Cement and Concrete Research, vol. 35 ,2005,pp: 1092-1105.

Benachour, Y., Davy, C.A. , Skoczylas, F., Houari, H., " Effect of a high calcite filler ddition upon microstructural, mechanical, shrinkage and transport properties of a mortar", Cement and Concrete Research, vol.38, 2008, pp.727-736.. 
Bédérina, M., Khenfer, M.M., Dheilly, R.M., Quéneudec, M., "Reuse of local sand: effect of limestone filler proportion on the rheological and mechanical properties of different sand concretes", cement concrete researches, vol. 35,2005,pp. 1172-1179

Ravindrarajah, R., Lopez, R. and Reslan, H., "Effect of Elevated Temperature on the Properties of High Strength Concrete Containing Cement Supplementary Materials", Center of Built Infrastructure Research, University of Technology, Sydney, Australia, March, 2002, pp. 1 - 9.

Moosberg-Bustnes, H.,, Lagerblad, B., Forssberg, E., "The function of fillers in concrete", Material Structure, vol. 37, 2004, pp: 74-81.

Lawrence, P., Cyr, M., Ringot, E., "Mineral admixtures in mortars: effect of type, amount and fineness of fine constituents on compressive strength", Cement and Concrete Research, vol. 35, 2005, pp: 1092-1105.

Celik, T., Mamer, K., "Effects of crushed stone dust on some properties for concrete", Cement and Concrete Research, vol. 26, 1996, p.p: 1121-1130.

Poon,C.S., Azhar,S.,Anson,M.,Wong,Y.L. "Comparison of the strength and durability of normal and high strength pozzolanic concrete at elevated temperature", Cement and Concrete Research, 2001, pp:1291-1300

Chan, Y.N.S., Peng, G.F., Anson, M., "residual strength and pore structure of high strength concrete and normal strength concrete ", Cement and Concrete Composites, 1999, pp: 23-27. 


\section{Appendix A:}

Initial Setting time and slump

\begin{tabular}{|c|c|c|}
\hline mix & In. setting time $(\mathrm{min})$ & Slump $(\mathrm{mm})$ \\
\hline LPC-0 & 120 & 75 \\
\hline LPC-10 & 105 & 72 \\
\hline LPC-15 & 75 & 75 \\
\hline LPC-20 & 75 & 80 \\
\hline LPC-25 & 90 & 83 \\
\hline
\end{tabular}

Compressive strength of investigated concrete (MPa)

\begin{tabular}{|c|c|c|c|c|c|}
\hline & \multicolumn{5}{|c|}{ \% Replacement of cement with L.P } \\
Tem ${ }^{\circ} \mathrm{C}$ & $0 \%$ & $10 \%$ & $15 \%$ & $20 \%$ & $25 \%$ \\
\hline 20 & 35.15 & 35.32 & 38.3 & 37.2 & 34.5 \\
\hline 200 & 30.57 & 31.55 & 32.17 & 31.47 & 28.53 \\
\hline 400 & 32.15 & 32.37 & 34.2 & 33.12 & 30.2 \\
\hline 600 & 25.18 & 25.51 & 26.3 & 25.1 & 23.2 \\
\hline
\end{tabular}

Splitting tensile strength of investigated concrete (MPa)

\begin{tabular}{|c|c|c|c|c|c|}
\hline \multirow{2}{*}{ Tem ${ }^{\circ} \mathrm{C}$} & \multicolumn{5}{|c|}{ \% Replacement of cement with L.P } \\
\hline 20 & 3.67 & 3.75 & 4.17 & 4.04 & 3.54 \\
\hline 200 & 3.2 & 3.07 & 3.41 & 3.31 & 2.59 \\
\hline 400 & 2.65 & 2.65 & 2.47 & 2.35 & 2.25 \\
\hline 600 & 1.73 & 1.72 & 1.69 & 1.6 & 1.53 \\
\hline
\end{tabular}

